\title{
Validating genetic risk associations for ovarian cancer through the international Ovarian Cancer Association Consortium
}

\section{Pearce*,1, AM Near'2, DJ Van Den Berg ${ }^{3}$, SJ Ramus ${ }^{4}$, A Gentry-Maharaj ${ }^{5}$, U Menon ${ }^{5}$, SA Gayther ${ }^{4}$,

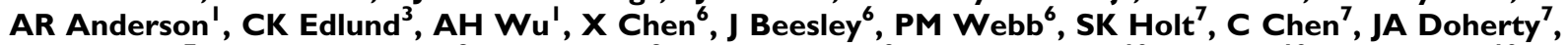 MA Rossing ${ }^{7}$, AS Whittemore ${ }^{8}$, V McGuire ${ }^{8}$, RA DiCioccio 9 , MT Goodman ${ }^{10}$, G Lurie ${ }^{10}$, ME Carney ${ }^{10}$, LR Wilkens ${ }^{\prime 0}$, RB Ness', KB Moysich ${ }^{12}$, R Edwards' ${ }^{13}$, E Jennison ${ }^{14}$, SK Kjaer $^{15}$, E Hogdall ${ }^{15}$, CK Hogdall ${ }^{16}$, EL Goode ${ }^{17}$, TA Sellers ${ }^{18}$, RA Vierkant ${ }^{17}$, JC Cunningham ${ }^{17}$, JM Schildkraut ${ }^{19}$, A Berchuck ${ }^{20}$, PG Moorman ${ }^{19}$, ES Iversen ${ }^{21}$, DW Cramer ${ }^{22}$, KL Terry ${ }^{22}$, AF Vitonis ${ }^{22}$, L Titus-Ernstoff ${ }^{23}$, H Song ${ }^{24}$, PDP Pharoah ${ }^{24}$, AB Spurdle ${ }^{6}$, H Anton-Culver ${ }^{25}$, A Ziogas ${ }^{25}$, W Brewster ${ }^{26}$, V Galitovskiy ${ }^{25}$, G Chenevix-Trench ${ }^{6}$, Australian Cancer Study (Ovarian Cancer) ${ }^{6}$ and Australian Ovarian Cancer Study Group ${ }^{6,27}$ on behalf of the Ovarian Cancer Association Consortium}

'Department of Preventive Medicine, Keck School of Medicine, University of Southem California, Los Angeles, CA, 90033, USA; '2Department of Epidemiology, University of Michigan School of Public Health, Ann Arbor, Michigan, 48105, USA; ${ }^{3}$ Keck School of Medicine, University of Southem California, Los Angeles, CA, 90033, USA; ${ }^{4}$ Gynaecological Cancer Research Laboratories, UCL EGA Institute for Women's Health, University College London, London, WCIE 6DD, UK; ${ }^{5}$ UCL EGA Institute for Women's Health, Gynaecological Cancer Research Centre, London, WIT 7DN, UK; ${ }^{6}$ The Queensland Institute of Medical Research, Post Office Royal Brisbane Hospital, Herston, Brisbane, QLD 4029, Australia; ${ }^{7}$ Epidemiology Program, Division of Public Health Sciences, Fred Hutchinson Cancer Research Center, Seattle, WA 98109-1024, USA; ${ }^{8}$ Department of Health Research and Policy, Division of Epidemiology, Stanford University School of Medicine, Stanford, CA 94305, USA; ${ }^{9}$ Department of Cancer Genetics, Roswell Park Cancer Institute, Buffalo, NY 14263, USA; ${ }^{10}$ Cancer Research Center, University of Hawaii, Honolulu, Hawaii, 968/3, USA; "'The University of Texas School of Public Health, Houston, TX 77030, USA; ${ }^{2}$ Department of Cancer Prevention and Control, Roswell Park Cancer Institute, Buffalo, NY, 14263, USA; ${ }^{13}$ Department of OB/GYNIRS, Magee-Women's Hospital, University of Pittsburgh Medical Center, Pittsburgh, PA 15213, USA; ${ }^{14}$ Gynecologic Oncologists of Northeast Ohio, Akron, OH 44302, USA; ${ }^{15}$ Department of Virus, Hormones and Cancer, Institute of Cancer Epidemiology, Danish Cancer Society, 2100 Copenhagen, Denmark; ${ }^{16}$ Gynaecologic Clinic, Juliane Marie Centre, Rigshospitalet, University of Copenhagen, 2100 Copenhagen, Denmark; ${ }^{17}$ Mayo Clinic College of Medicine, Rochester, MN, 55905, USA; ${ }^{18}$ H. Lee Moffitt Cancer Center and Research Institute, MRC CANCONT, Tampa, FL, 336 12, USA; ${ }^{19}$ Cancer Prevention and Control Research Program, Duke University Medical Center, Durham, NC 277I 0 USA; ${ }^{20}$ Division of Gynecologic Oncology, Duke University Medical Center, Durham, NC, 277 I0, USA; ${ }^{21}$ Department of Statistical Sciences, Duke University, Durham, NC 27708-025I, USA; ${ }^{22}$ Brigham and Women's Hospital, Boston, MA 0211 5, USA; ${ }^{23}$ Department of Community and Family Medicine and of Pediatrics, Dartmouth Medical School, Lebanon, NH 03756, USA; ${ }^{4}$ Strangeways Research Laboratory, Department of Oncology, University of Cambridge, Cambridge, CBI 8RN, UK; ${ }^{25}$ Department of Epidemiology, School of Medicine, University of Califomia, Irvine, CA 92697, USA; ${ }^{26}$ Department of OB/GYN, UCI Medical Center, Chao Clinical Cancer Center, Orange, CA 92868, USA; ${ }^{27}$ Peter MacCallum Cancer Centre, East Melboume, VIC 3002, Australia

The search for genetic variants associated with ovarian cancer risk has focused on pathways including sex steroid hormones, DNA repair, and cell cycle control. The Ovarian Cancer Association Consortium (OCAC) identified 10 single-nucleotide polymorphisms (SNPs) in genes in these pathways, which had been genotyped by Consortium members and a pooled analysis of these data was conducted. Three of the 10 SNPs showed evidence of an association with ovarian cancer at $P \leqslant 0.10$ in a log-additive model: rs2740574 in CYP3A4 $(P=0.01 \mathrm{I})$, rs I 805386 in LIG4 $(P=0.007)$, and rs32I8536 in XRCC2 $(P=0.095)$. Additional genotyping in other OCAC studies was undertaken and only the variant in CYP3A4, rs2740574, continued to show an association in the replication data among homozygous carriers: $O R_{\text {homozygous }(\text { hom })}=2.50(95 \% \mathrm{Cl} 0.54-11.57, P=0.24)$ with 1406 cases and 2827 controls. Overall, in the combined data the odds ratio was 2.81 among carriers of two copies of the minor allele $(95 \% \mathrm{Cl} 1.20-6.56, P=0.017$, Phet across studies $=0.42)$ with 1969 cases and $349 \mid$ controls. There was no association among heterozygous carriers. CYP3A4 encodes a key enzyme in oestrogen metabolism and our finding between rs2740574 and risk of ovarian cancer suggests that this pathway may be involved in ovarian carcinogenesis. Additional follow-up is warranted.

British Journal of Cancer (2009) I 00, 4I2-420. doi:I0.1038/sj.bjc.6604820 www.bjcancer.com

Published online 6 January 2009

(c) 2009 Cancer Research UK

Keywords: ovarian cancer; genetic susceptibility; oestrogen metabolism; CYP3A4; pooled-analyses

*Correspondence: Assistant Professor CL Pearce;

E-mail: cpearce@usc.edu

Received 12 August 2008; revised II November 2008; accepted 18

November 2008; published online 6 January 2009 
Ovarian cancer is the second most common gynaecologic cancer and the leading cause of gynaecologic cancer death; it is estimated that there were $\sim 22000$ new diagnoses of ovarian cancer and $\sim 15000$ deaths from the disease in the United States in 2007. In some families Mendelian inheritance of ovarian cancer is observed and high penetrance alleles have been identified in several genes including BRCA1, BRCA2, and DNA mismatch repair genes. However, disease-associated alleles of these genes account for less than $40 \%$ of the inherited variance in disease risk (Antoniou and Easton, 2006). Population-based case-control studies have described a two to three-fold increased risk in first-degree relatives of ovarian cancer patients (Godard et al, 1998; Stratton et al, 1998) and heritability is estimated to be approximately $22 \%$ (Lichtenstein et al, 2000). Ovarian cancer is probably a complex genetic disease with locus and allelic heterogeneity (Lander and Schork, 1994), and such complex traits are likely to be because of combinations of common, less penetrant alleles (Risch and Merikangas, 1996). However, the common alleles that might be responsible for susceptibility to ovarian cancer remain poorly understood.

The most powerful approach for identifying common, lowpenetrance disease susceptibility alleles is the genetic association study. Until recently, most association studies have focused on the candidate gene approach in which common genetic variation in biologically relevant pathways is tested for association with disease. However, this approach has had limited success, and few initial findings of positive associations have been replicated in subsequent studies (Ioannidis et al, 2001; Lohmueller et al, 2003). One of the main reasons for these failures has been the limited power of small studies to detect associations at highly stringent levels of statistical significance. This is a particular problem in ovarian cancer where the largest individual studies have fewer than 2000 cases.

The Ovarian Cancer Association Consortium (OCAC) was formed in 2005 to provide a forum for testing candidate ovarian cancer susceptibility alleles in multiple studies with a large combined sample size (Gayther et al, 2007; Pearce et al, 2008; Ramus et al, 2008). Prior to the formation of the OCAC most groups had been carrying out candidate gene studies autonomously, although in many instances they had been studying the same candidate single nucleotide polymorphisms (SNPs) and genes. The purpose of the current study was to evaluate the evidence for association in SNPs, which had already been genotyped by multiple studies by combining the existing data. Where evidence for association emerged from these data, the associated SNPs were then genotyped in additional OCAC studies for replication.

\section{MATERIALS AND METHODS}

\section{Study populations}

The Ovarian Cancer Association Consortium is comprised of ovarian cancer case - control and cohort studies conducted around the world (Gayther et al, 2007; Pearce et al, 2008; Ramus et al, 2008). Included in this report are data from 16 OCAC studies. Ten of these are from the USA: the Diseases of the Ovary and their Evaluation (DOVE), the Genetic Epidemiology of Ovarian Cancer Study (GEOCS; previously FROCS) (Auranen et al, 2005; Song et al, 2006), the Hawaii Ovarian Cancer Study (HAWAII) (Goodman et al, 2001b), the Hormones and Ovarian Cancer Prediction Study (HOPE) (Pearce et al, 2008a), the Mayo Clinic Ovarian Cancer Case-Control Study (MAYO) (Sellers et al, 2005), the North Carolina Ovarian Cancer Study (NCOCS) (Berchuck et al, 2004), the New England-based Case-Control Study (Terry et al, 2005), the Ovarian Contraceptive and Reproductive Experiences study (Holt et al, 2007), the Orange and San Diego
Counties, California (UCI) study and the USC/Los Angeles County Case-Control Studies of Ovarian Cancer (USC) (Pearce et al, 2008b). There are data from three European studies: the Danish Malignant Ovarian Cancer Study (MALOVA) (Auranen et al, 2005; Song et al, 2006), the UK SEARCH Ovarian Cancer Study (SEARCH) (Auranen et al, 2005; Song et al, 2006), and the UK Ovarian Population Study (UKOPS) (Ramus et al, 2008). Finally, data were contributed by three studies from Australia: the Australian Cancer Study (ACS) (Merritt et al, 2008), the Australian Ovarian Cancer Study (AOCS) (Merritt et al, 2008), and Survey of Women's Health (SWH) (Spurdle et al, 2000). ACS and AOCS were combined for analysis purposes. Details of all but DOVE and UCI have been published earlier.

All studies have Institutional Review Board/Human Ethics Committee approval for the work presented. In addition, Duke University and the University of Southern California have Institutional Review Board approval as data coordinating centers.

\section{SNP selection}

At the inception of the OCAC and annually thereafter, members have provided a list of SNPs genotyped in their study population. By early 2007, there were 10 SNPs which had been genotyped by at least three groups: rs4680 in COMT, rs4646903 and rs1048943 in CYP1A1, rs1056836 in CYP1B1, rs2740574 in CYP3A4, rs743572 in CYP17, rs3020450 in ESR2, rs1805386 in LIG4, rs3218536 in XRCC2 and rs861539 in XRCC3. Some of these data have earlier been published by individual groups (Spurdle et al, 2000, 2002; Goodman et al, 2001a,b; Garner et al, 2002; Terry et al, 2003; Auranen et al, 2005; Sellers et al, 2005; Webb et al, 2005; Beesley et al, 2007; Holt et al, 2007; Pearce et al, 2008b). The original data on these 10 SNPs were then submitted to a central database for combined analysis. SNPs that showed some evidence for association in original data were also genotyped in additional OCAC studies for replication purposes.

\section{Genotyping and quality control}

The original data had been genotyped using a variety of methods described in the reports of these individual data (see Table 1 for references). For the replication genotyping, the $5^{\prime}$ nuclease Taqman allelic discrimination assay (Taqman; Applied Biosystems, Foster City, CA, USA) was used by DOVE, HAWAII, HOPE, MALOVA, MAYO, SEARCH, UCI, UKOPS and USC using centrally supplied probes. ACS and AOCS used the Sequenom iPlex gold genotyping platform (Sequenom Inc., San Diego, CA, USA).

For all genotype data, genotype frequencies by ethnic group and study in controls were tested for deviation from Hardy-Weinberg equilibrium (HWE). For the replication genotyping effort, we applied the OCAC quality control guidelines which stipulated intermixing of cases and controls on genotyping plates, including duplicate samples with no less than $98 \%$ concordance rate, overall call rate by each study of $95 \%$ or greater and call rate for each plate of at least $90 \%$. In addition, consistency across labs was confirmed by genotyping a common set of 95 DNAs ( $90 \mathrm{CEPH}$ trios and five duplicate samples; HAPMAPPT01 provided by Coriell, Camden, NJ, USA) with the requirement of $>98 \%$ concordance in genotype calls.

\section{Data analysis}

Each group provided age and race/ethnicity for all participants and tumour histology for cases. Data analyses were restricted to invasive epithelial ovarian cancers and included White, Black and Latina individuals. Unconditional logistic regression stratified on study, age (five groups: $<40,40-49,50-59,60-69,70+$ years), and race/ethnicity, was used to analyze the data (SAS Version 9.1, Cary, NC, USA). Each SNP was evaluated under three genetic models: a co-dominant log additive model, a dominant model and 
Table I Characteristics of the OCAC case-control studies included in this report

\begin{tabular}{|c|c|c|c|c|c|c|}
\hline Study (Ref) ${ }^{a}$ & Location & $\begin{array}{l}\text { Years } \\
\text { conducted }\end{array}$ & Control ascertainment & Case ascertainment & $\begin{array}{l}\text { No. of controlsl } \\
\text { cases }\end{array}$ & SNPs genotyped \\
\hline ACS & Australia & $2002-2005$ & $\begin{array}{l}\text { Randomly selected from } \\
\text { Commonwealth electoral roll. } \\
\text { Frequency matched for age and } \\
\text { geographical region. }\end{array}$ & $\begin{array}{l}\text { Cancer registries of New South Wales and } \\
\text { Victoria. }\end{array}$ & $364 / 166$ & rs2740574 (CYP3A4), rs 805386 (LIG4) \\
\hline $\begin{array}{l}\text { AOCS (Beesley } \\
\text { et al, 2007) }\end{array}$ & Australia & $2002-2006$ & $\begin{array}{l}\text { Randomly selected from } \\
\text { Commonwealth electoral roll. } \\
\text { Frequency matched for age \& } \\
\text { geographical region. }\end{array}$ & $\begin{array}{l}\text { Recruited through surgical treatment } \\
\text { centres throughout Australia and cancer } \\
\text { registries of Queensland, South Australia } \\
\text { and West Australia. }\end{array}$ & $698 / 558$ & $\begin{array}{l}\text { rs2740574 CYP3A4), rs } 805386 \text { (LIG4), } \\
\text { rs32। } 8536 \text { (XRCC2), rs861539 (XRCC3) }\end{array}$ \\
\hline DOVE & Washington, USA & $2002-2005$ & $\begin{array}{l}\text { Random-digit dial identification } \\
\text { from study area. Frequency } \\
\text { matched to cases for race/ethnicity } \\
\text { and 5-year age group. }\end{array}$ & $\begin{array}{l}\text { Cases diagnosed with primary invasive } \\
\text { ovarian cancer between } 2002-2005 \text { from } \\
\text { a 13-county area of western Washington } \\
\text { state. }\end{array}$ & $744 / 548$ & rs3218536 (XRCC2) \\
\hline $\begin{array}{l}\text { GEOCS (Auranen } \\
\text { et al, 2005) }\end{array}$ & $\begin{array}{l}\text { Northern } \\
\text { California, USA }\end{array}$ & $1997-2002$ & $\begin{array}{l}\text { Random-digit dial identification } \\
\text { from study area. Frequency } \\
\text { matched to cases for } 5 \text {-year age } \\
\text { group and race/ethnicity. }\end{array}$ & $\begin{array}{l}\text { Greater Bay Area Cancer Registry, } \\
\text { San Francisco. }\end{array}$ & $419 / 317$ & $\begin{array}{l}\text { rs } 1805386 \text { (LIG4), rs32। } 8536 \text { (XRCC2), } \\
\text { rs861539 (XRCC3) }\end{array}$ \\
\hline $\begin{array}{l}\text { HAWAll } \\
\text { (Goodman et al, } \\
200 \text { la, b) }\end{array}$ & Hawaii, USA & 1993 onwards & $\begin{array}{l}\text { Randomly selected from Hawaii } \\
\text { Department of Health Annual } \\
\text { Survey of the representatives } \\
\text { households. }\end{array}$ & $\begin{array}{l}\text { Rapid case ascertainment through Hawaii } \\
\text { Tumour Registry. }\end{array}$ & $160 / 70$ & $\begin{array}{l}\text { rs4680 (COMT), rs4646903 (CYPIAI), } \\
\text { rsI } 048943 \text { (CYPIAI), rs I } 056836 \\
\text { (CYPIBI), rs2740574 (CYP3A4), rs743572 } \\
\text { (CYPI7), rs3020450 (ESR2), rs32I } 8536 \\
\text { (XRCC2) }\end{array}$ \\
\hline HOPE & $\begin{array}{l}\mathrm{NY}, \mathrm{OH} \text { and } \mathrm{PA} \text {, } \\
\text { USA }\end{array}$ & 2003 onwards & $\begin{array}{l}\text { Identified in same regions. } \\
\text { Frequency matched for age and } \\
\text { ethnicity. }\end{array}$ & $\begin{array}{l}\text { Physician offices, cancer registries and } \\
\text { pathology databases from counties of } \\
\text { western PA, eastern } \mathrm{OH} \text { and western NY. }\end{array}$ & $662 / 297$ & RS3218536 (XRCC2) \\
\hline $\begin{array}{l}\text { MALOVA } \\
\text { (Auranen et al, } \\
\text { 2005) }\end{array}$ & Denmark & $1994-1999$ & $\begin{array}{l}\text { Random sample of general female } \\
\text { population ( } 35-79 \text { years of age) in } \\
\text { study area. Selected using } \\
\text { computerised Central Population } \\
\text { Register and matched to cases for } \\
\text { age and geographical region. }\end{array}$ & $\begin{array}{l}\text { Incident cases ( } 35-79 \text { years of age) from } \\
\text { municipalities of Copenhagen and } \\
\text { Frederiksberg and surrounding counties. }\end{array}$ & $1197 / 42$ & $\begin{array}{l}\text { rs2740574 (CYP3A4), rs } 1805386 \text { (LIG4), } \\
\text { rs3218536 (XRCC2), rs861539 (XRCC3) }\end{array}$ \\
\hline $\begin{array}{l}\text { MAYO (Sellers } \\
\text { et al, 2005) }\end{array}$ & Mayo Clinic, USA & 2000 onwards & $\begin{array}{l}\text { Healthy women seeking general } \\
\text { medical examination identified } \\
\text { through Mayo Clinic. Frequency } \\
\text { matched to cases for age, race, and } \\
\text { state of residence. }\end{array}$ & $\begin{array}{l}\text { Cases attending Mayo Clinic identified in a } \\
\text { six-state surrounding region. }\end{array}$ & $442 / 325$ & $\begin{array}{l}\text { rs4680 (COMT), rs I } 048943 \text { (CYPIAI), } \\
\text { rs I } 056836 \text { (CYPIBI), rs32 I8536 (XRCC2) }\end{array}$ \\
\hline NCOCS & $\begin{array}{l}\text { North Carolina, } \\
\text { USA }\end{array}$ & 1999 onwards & $\begin{array}{l}\text { Controls identified from same } \\
\text { region. Frequency matched to cases } \\
\text { for age and race. }\end{array}$ & $\begin{array}{l}\text { Identified from } 48 \text { counties within the } \\
\text { region by rapid-case ascertainment. }\end{array}$ & $941 / 702$ & $\begin{array}{l}\text { rs2740574 (CYP3A4), rs743572 (CYPI7), } \\
\text { rs3020450 (ESR2), rs I805386(LIG4), } \\
\text { rs3218536(XRCC2), rs861539 (XRCC3) }\end{array}$ \\
\hline $\begin{array}{l}\text { NECC (Garner } \\
\text { et al, 2002; Terry } \\
\text { et al, 2003) }\end{array}$ & $\begin{array}{l}\text { New England, } \\
\text { USA }\end{array}$ & $1992-2003$ & $\begin{array}{l}\text { Controls identified through random } \\
\text { digit dialing, townbooks, and } \\
\text { drivers' license lists. Frequency } \\
\text { matched to cases on age and state } \\
\text { of residence. }\end{array}$ & $\begin{array}{l}\text { Identified through hospital tumour boards } \\
\text { and state cancer registries in New } \\
\text { Hampshire and Massachusetts. }\end{array}$ & $484 / 268$ & $\begin{array}{l}\text { rs4646903 (CYPIAI), rsI } 048943 \\
\text { (CYPIAI), rs743572 (CYPI7), rs3020450 } \\
\text { (ESR2) }\end{array}$ \\
\hline $\begin{array}{l}\text { OVCARE (Holt } \\
\text { et al, 2007) }\end{array}$ & Washington, USA & $1994-1998$ & $\begin{array}{l}\text { Controls identified through random } \\
\text { digit dialing in same three } \\
\text { geographic regions as cases. }\end{array}$ & $\begin{array}{l}\text { Incident cases ( } 35-54 \text { years of age) } \\
\text { identified by SEER population-based cancer } \\
\text { registries serving metropolitan Atlanta, } \\
\text { Detroit, and Seattle areas. }\end{array}$ & $577 / 188$ & $\begin{array}{l}\text { rs } 4680 \text { (COMT), rs4646903 (CYPIAI), } \\
\text { rs I } 048943 \text { (CYPIAI), rs } 056836 \\
\text { (CYPIBI) }\end{array}$ \\
\hline $\begin{array}{l}\text { SEARCH (Auranen } \\
\text { et al, 2005) }\end{array}$ & UK & 199| onwards & $\begin{array}{l}\text { Selected from the EPIC-Norfolk } \\
\text { cohort of } 25,000 \text { individuals aged } \\
45-74 \text {, based in the same }\end{array}$ & $\begin{array}{l}\text { Caese }<70 \text { years from East Anglian, West } \\
\text { Midlands \& Trent regions of England. } \\
\text { Prevalent cases diagnosed } 199 \mid-1998 ;\end{array}$ & $|22| / 85 \mid$ & $\begin{array}{l}\text { rs } 1805386 \text { (LIG4), rs32। } 8536 \text { (XRCC2), } \\
\text { rs861539 (XRCC3) }\end{array}$ \\
\hline
\end{tabular}




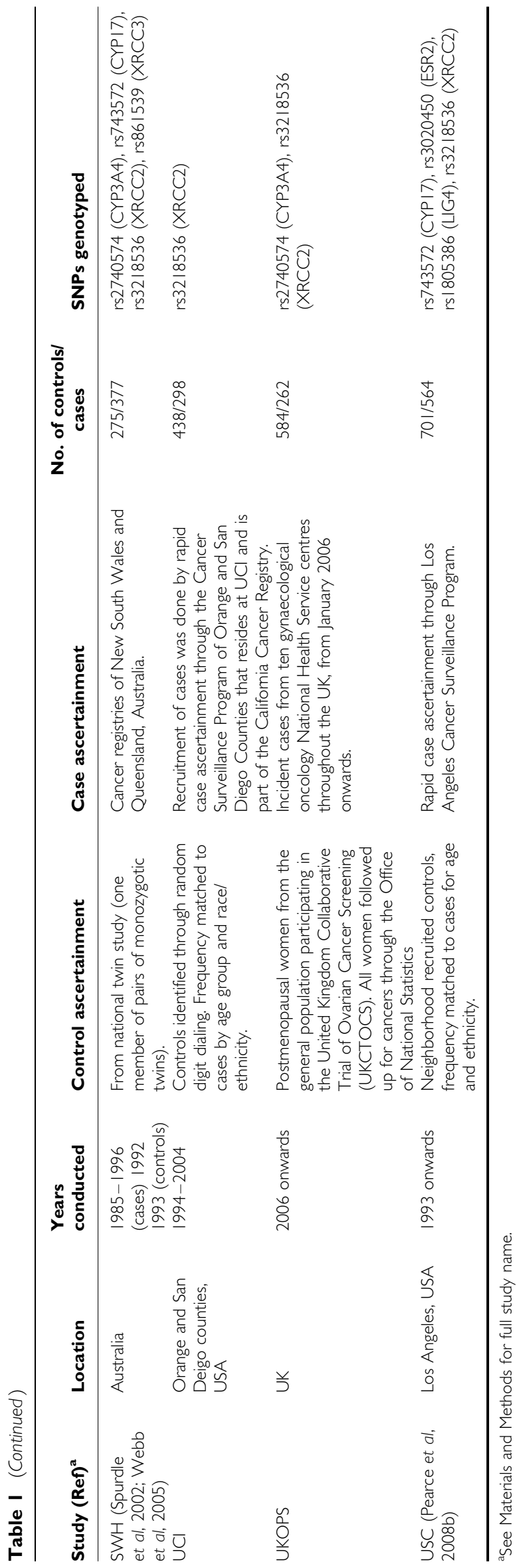

a recessive model. Results are given for the heterozygous and homozygous risk estimates.

Information on a first-degree family history of ovarian cancer was available on approximately $75 \%$ of cases and controls. Stratified analyses were conducted on this subset of subjects.

The original and replication data were analyzed separately and combined using the same methods. Heterogeneity across studies was tested using the likelihood ratio test by fitting models with and without interaction terms for study and SNP based on the final model presented in the results.

Published data from non-OCAC members were available on three SNPs: rs4680 (COMT) (Goodman et al, 2000), rs4646903 (CYP1A1, also known as CYP1A1 Msp1) (Sugawara et al, 2003) and rs1048943 (CYP1A1, also known as CYP1A1*3) (Aktas et al, 2002; Sugawara et al, 2003). The odds ratios and 95\% confidence intervals from these published reports were abstracted and a metaanalysis was conducted utilizing these data as well as the OCAC data using Stata (Version 9, StataCorp, College Station, TX, USA). Both random and fixed-effects models were evaluated.

\section{RESULTS}

Details of the 16 case-control studies that provided data for these analyses are shown in Table 1. Genotype frequencies in White controls were consistent with HWE for all SNPs/studies except rs2740574 (CYP3A4) in HAW $(P=0.04)$ (Supplementary Table 1). These data were retained in the analyses as the deviation was small, the clustering was unambiguous and given the number of SNP/ study combinations evaluated it is likely to represent a chance finding.

Seven of the 10 SNPs showed no evidence of an association with invasive epithelial ovarian cancer (ovarian cancer; Table 2). These SNPs were not further evaluated in the OCAC, but three of them (COMT rs4680, CYP1A1 rs4646903, and CYP1A1 1048943) had been studied by groups outside of the OCAC and thus meta-analyses of the published literature and OCAC data were conducted. Neither the COMT variant nor the CYP1A1 rs4646903 variant were statistically significantly associated with ovarian cancer risk on meta-analysis (data not shown).

The CYP1A1 rs1048943 which showed a non-statistically significant $10 \%$ increased risk of ovarian cancer per copy of the minor allele carried in the OCAC dataset (95\% CI 0.77-1.57) was statistically significantly associated with risk of ovarian cancer on meta-analysis with the published literature and the OCAC data $\left(\mathrm{OR}_{\text {additive }(\mathrm{add})}=1.81,95 \% \mathrm{CI} 1.36-2.40, P<0.001\right)$ under a fixed effects model, but not a random-effects model $\left(\mathrm{OR}_{\mathrm{add}}=1.61,95 \%\right.$ CI $0.74-3.51, P=0.23)$. The meta-analysis also revealed significant heterogeneity across studies $(P<0.001)$.

Three SNPs showed evidence of an association with ovarian cancer in the original OCAC data and were evaluated in additional case-control studies from OCAC members (Table 3; Figure 1). Based on original genotype data (three studies: 563 cases, 664 controls), CYP3A4 rs2740574 was associated with an increased risk of invasive ovarian cancer among women who carried two copies of the minor allele $(P=0.015)$. There was a 3.7 -fold increased risk associated with carrying two copies of the minor allele. Similar results were found when this SNP was genotyped by three additional OCAC sites in an additional 1406 cases and 2827 controls, but the confidence interval was wide $\left(\mathrm{OR}_{\text {homozygous }(\text { hom })}=2.50,95 \%\right.$ CI $0.54-11.54, P=0.24$; Table 3$)$ because the follow-up data consisted of White individuals in which the minor allele frequency was very low. In the combined dataset, women carrying two copies of this allele had a 2.8 -fold increased risk of ovarian cancer $\left(\mathrm{OR}_{\text {hom }}=2.81,95 \%\right.$ CI 1.20-6.56, $\mathrm{p}_{\text {hom }}=0.017$; Table 3 ; Figure 1). There was no evidence of heterogeneity across study sites $\left(\mathrm{p}_{\text {het }}=0.42\right)$. This finding was 
Table 2 Summary odds ratio (per allele) and 95\% confidence interval for risk of invasive epithelial ovarian cancer among the indicated OCAC studies for SNPs that showed no association with ovarian cancer

\begin{tabular}{|c|c|c|c|c|c|c|c|c|}
\hline Gene & SNP & $\begin{array}{c}\text { Controls } \\
\text { (N) }\end{array}$ & $\begin{array}{c}\text { Cases } \\
(\mathbf{N})\end{array}$ & $\begin{array}{l}\text { OR }_{\text {het }}^{a} \\
(95 \% \text { CI })\end{array}$ & $P$-value & $\begin{array}{l}\text { OR }_{\text {hom }}^{a} \\
(95 \% \text { CI) }\end{array}$ & $P$-value & Studies \\
\hline COMT & rs4680 & 874 & 381 & $1.01(0.75-1.36)$ & 0.96 & $1.00(07 \mid-1.42)$ & 0.98 & HAWAII, MAYO OVCARE \\
\hline CYPIAI & rs4646903 & 1182 & 490 & $1.15(0.89-1.50)$ & 0.29 & $0.77(0.28-2.13)$ & 0.61 & HAWAII, NECC, OVCARE \\
\hline CYPIAI & rs 1048943 & 1308 & 611 & $1.13(0.79-1.63)$ & 0.50 & - & 0.97 & HAWAII, MAYO, NECC, OVCARE \\
\hline CYPIBI & rs 1056836 & 875 & 384 & $0.91(0.69-1.21)$ & 0.52 & $0.83(0.58-1.19)$ & 0.31 & HAWAII, MAYO OVCARE \\
\hline CYPI7 & rs743572 & 1594 & 1078 & $1.09(0.91-1.30)$ & 0.36 & $1.19(0.93-1.52)$ & 0.17 & HAWAII, NCOCS, NECC, SWH, USC \\
\hline ESR2 & rs3020450 & 2198 & 1523 & $0.95(0.83-1.10)$ & 0.52 & $1.09(0.87-1.36)$ & 0.44 & HAWAII, NCOCS, NECC, USC \\
\hline$X \mathrm{RCC} 3$ & rs861539 & 5186 & 2352 & $0.92(0.82-1.04)$ & 0.17 & $1.01(0.85-1.19)$ & 0.95 & AOCS, MALOVA, NCOCS, SEARCH, GEOCS, SWH \\
\hline
\end{tabular}

${ }^{\mathrm{a}} \mathrm{Cl}=$ confidence interval; het = heterozygous carriers; hom = homozygous carriers; OR = odds ratio. All ORs stratified on study site, race/ethnicity and age.

Table 3 Summary odds ratio and 95\% confidence interval for risk of invasive epithelial ovarian cancer among OCAC studies for the three SNPs associated with risk of ovarian cancer in original data

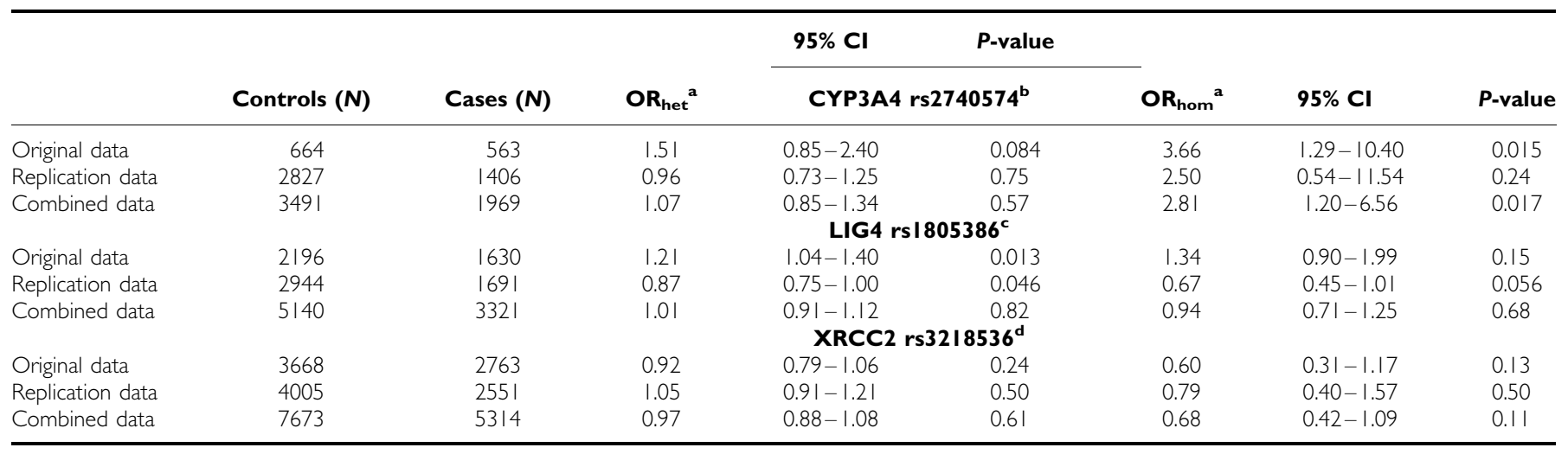

ahet = heterozygous carriers; OR = odds ratio; hom = homozygous carriers. ' ${ }^{\circ}$ Studies included in original data: HAWAll, NCOCS, SWH; studies included in follow-up data: ACS, AOCS, MALOVA, UKOPS. 'Studies included in original data: GEOCS, NCOCS, SEARCH; studies included in follow-up data: ACS, AOCS, MALOVA, USC. 'Studies included in original data: AOCS, GEOCS, MALOVA, NCOCS, SEARCH, SWH; studies included in follow-up data DOVE, HAWAll, HOPE, MAYO, SEARCH (additional accrued cases), UCI, UKOPS, USC.

consistent across histological subtypes (Table 4). There was no evidence of statistical interaction with family history $(P=0.52)$.

The minor allele frequency for rs2740574 in White controls was $3.5 \%$, compared with $59.7 \%$ in Blacks. The association between this CYP3A4 variant and risk of ovarian cancer was consistent across these two racial/ethnic groups in the combined existing and follow-up data: $\mathrm{OR}_{\text {hom }}$ in Blacks $=6.82(95 \%$ CI $0.73-63.86$, $P=0.093)$ and $\mathrm{OR}_{\mathrm{hom}}$ in Whites $=2.40(95 \%$ CI $0.67-8.68$, $P=0.18)$.

There was a $21 \%$ increased risk of ovarian cancer associated with the rs1805386 variant in LIG4 among heterozygous carriers and a $34 \%$ increased risk among homozygous carriers $(P=0.013$ and $P=0.15$, respectively; Table 3 ) in the original data. When this SNP was genotyped by four additional OCAC sites (1691 cases and 2944 controls) a decreased risk of ovarian cancer was observed $\left(\mathrm{OR}_{\text {heterozygous (het) }}=0.87, P=0.046\right.$ and $\mathrm{OR}_{\text {hom }}=0.67, P=0.056$; Table 3). After combining the original and replication data there was no association between rs 1805386 and risk of ovarian cancer $\left(\mathrm{OR}_{\text {het }}=0.97, P=0.61, \mathrm{OR}_{\text {hom }}=0.68, P=0.11\right.$; Table 3; Figure 1$)$ in 3321 cases and 5140 controls. There was a significant heterogeneity across the study sites $(P=0.001)$; the heterogeneity was not attributable to any single study. There was no evidence of statistical interaction with family history $(P=0.50)$.

We found borderline evidence of a decrease in ovarian cancer risk associated with the XRCC2 variant rs3218536 using a logadditive model in the original data provided by six OCAC sites ( $\mathrm{OR}=0.89,95 \% \mathrm{CI} 0.78-1.02, P=0.095)$ with 2763 cases and 5479 controls. This SNP was genotyped by seven additional OCAC sites comprising 2551 cases and 4005 controls and no association was observed with ovarian cancer risk (Table 3 ). In the combined data there was no association between rs3218536 and risk of ovarian cancer (Table 3; Figure 1). There was neither any evidence of heterogeneity across study sites $(P=0.30)$, nor histological subtype-specific effects. There was also no evidence of statistical interaction with family history $(P=0.25)$.

\section{DISCUSSION}

We evaluated the association between 10 SNPs from nine genes and ovarian cancer risk using existing data from 16 studies that participate in the OCAC. We found borderline evidence for association with ovarian cancer risk for three of these variants and replication genotyping was carried out to provide more definitive evidence of association. In the combined data, only rs2740574 in CYP3A4 was associated with disease among women who carried two copies of the minor allele $(P=0.017)$. This finding was consistent across the original and replication data and also across White and Black racial/ethnic groups and histological subtypes (Table 4).

CYP3A4 encodes an enzyme critical for oxidation of oestrogens (Keshava et al, 2004) and its inhibition results in higher circulating oestrogen levels (Monroe et al, 2007). Given that exposure to oestrogen is associated with the risk of ovarian cancer (Beral et al, 2007) it is plausible that the CYP3A4 rs2740574 variant might influence ovarian cancer development through decreased expression of the gene and thus reduced metabolism of oestrogen. In addition to hormone metabolism, CYP3A4 is also involved in the 
A

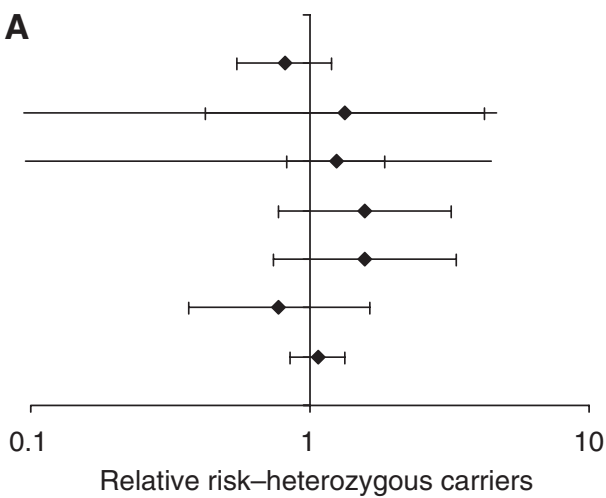

B

0.1

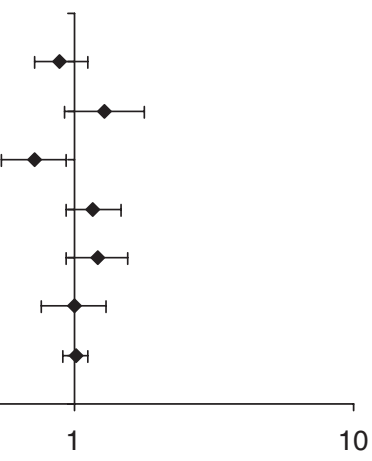

Relative risk-heterozygous carriers

C

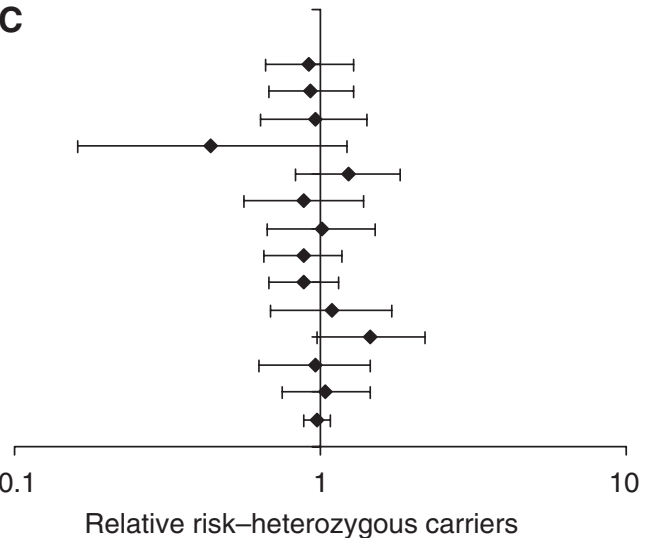

ACS/AOCS

HAWAII

MALOVA

NCOCS

SWH

UKOPS

Combined

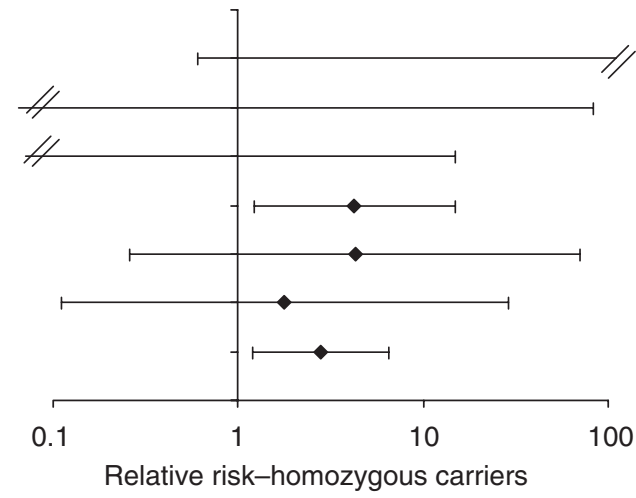

ACS/AOCS

GEOCS

MALOVA

NCOCS

SEARCH

USC

Combined
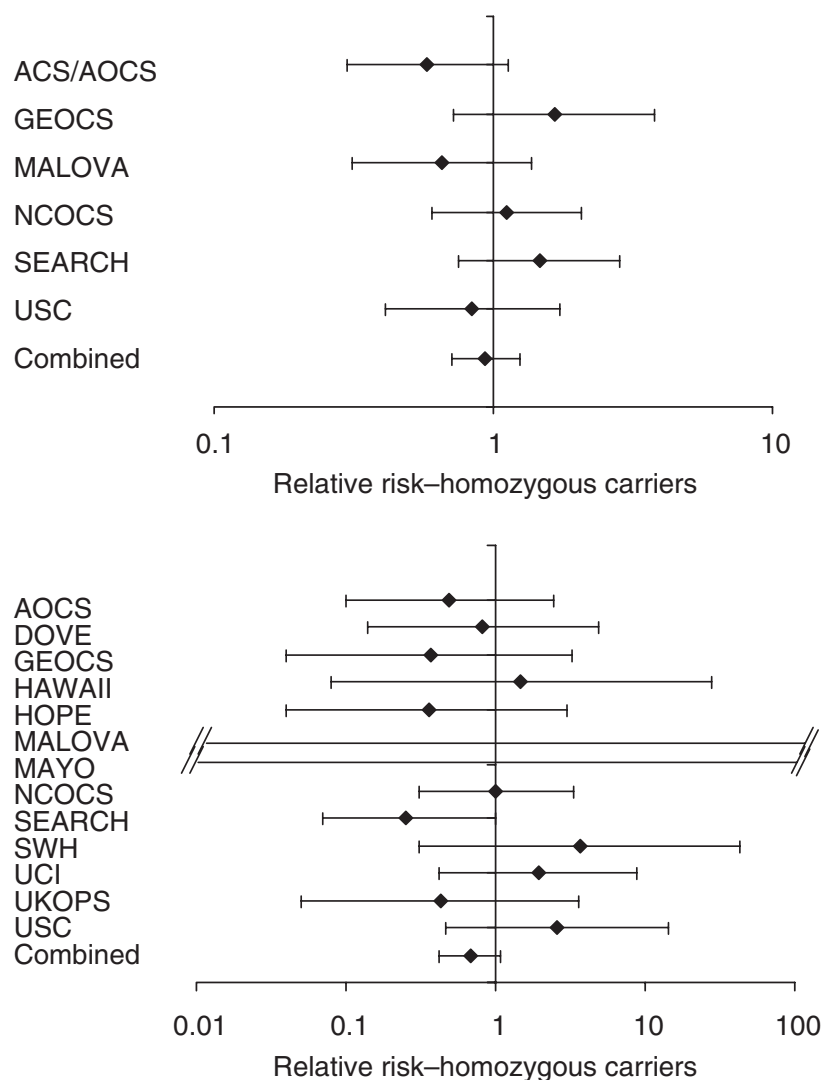

Figure I Forest plots of the study-specific and summary-relative risk and $95 \%$ confidence intervals for the association between ovarian cancer risk and three SNPs in the CYP3A4, LIG4 and XRCC2 genes. (A) rs2740574 in CYP3A4. The overall summary ovarian cancer risk among heterozygous carriers is $1.07(0.85-1.34, P=0.57)$ and homozygous carriers is $2.81(95 \% \mathrm{Cl} \mid .20-6.56, P=0.017)$. (B) rs $\mid 805386$ in LIG4. The overall summary ovarian cancer relative risk among heterozygous carriers is $1.01(95 \% \mathrm{Cl} 0.91-1.12, P=0.82)$ and homozygous carriers is $0.94(95 \% \mathrm{Cl} 0.71-1.25, P=0.68)$. (C) $r s 3218536$ in XRCC2. The overall summary ovarian cancer relative risk among heterozygous carriers is $0.97(95 \% \mathrm{Cl} 0.88-1.08, \mathrm{P}=0.61)$ and homozygous carriers $0.68(95 \% \mathrm{Cl} 0.42-1.09, P=0.1 \mathrm{I})$.

metabolism of approximately half of all marketed drugs, therefore individuals with differences in CYP3A4 expression might have different responses to any number of exogenous compounds, including oral contraceptives, an ovarian cancer protective factor.

The rs2740574 SNP is in the promoter region of the gene, but efforts to show a functional effect of this variant have proved difficult. Spurdle et al (2002) evaluated multiple reporter gene constructs, but found no differences in the transcription between the putative disease and wild-type allele; the results of other functional studies have been equivocal (Ball et al, 1999; Westlind et al, 1999; Amirimani et al, 2003; Rodriguez-Antona et al, 2005). Alternatively, it may be that rs 2740574 is simply in linkage disequilibrium with the causal variant, which remains to be identified. Using data from the International Haplotype
Map Project (HapMap) to examine the region that includes CYP3A4, CYP3A5 and CYP3A7 genes and the $20 \mathrm{~kb}$ flanking this region, there are six variants in perfect linkage disequilibrium with rs2740574. Five of these variants are in the region immediately $5^{\prime}$ of CYP3A4 and one is in intron 2 of the gene. Any of these SNPs, or an unidentified variant in linkage disequilibrium, could be the causal allele. At present, there are no data to support a functional role for any of these variants in ovarian cancer development. Additional follow-up is warranted to confirm the association between this CYP3A4 variant and risk of ovarian cancer, and ideally these studies should be performed in different racial groups.

Two additional variants, one in LIG4 and the other in XRCC2, evaluated as part of this project, showed association in the original 
Table 4 Odds ratios and 95\% Cls by race/ethnicity and histological sub-type ${ }^{a}$ for the CYP3A4 rs2740574 variant in the combined dataset

\begin{tabular}{lcccccccc}
\hline Characteristics & Cases & Controls & $\mathbf{O R}_{\text {het }} \mathbf{b}$ & $\mathbf{9 5 \%} \mathbf{C l}$ & $\boldsymbol{P}_{\text {-value }}$ & $\mathbf{O R}_{\text {hom }} \mathbf{b}$ & $\mathbf{9 5 \%} \mathbf{C l}$ & $\mathbf{P}_{\text {-value }}$ \\
\hline Black & 24 & 36 & 2.86 & $0.28-29.63$ & 0.38 & 6.82 & $0.73-63.86$ \\
White & 1944 & 3453 & 1.06 & $0.84-1.33$ & 0.62 & 2.4 & $0.67-8.68$ \\
Endometrioid & 229 & 3491 & 1.65 & $1.05-2.59$ & 0.03 & 2.64 & $0.36-19.16$ \\
Mucinous & 107 & $349 \mid$ & 0.54 & $0.19-1.51$ & 0.24 & 4.75 & $0.47-47.84$ & 0.34 \\
Serous & 1052 & $349 \mid$ & 0.93 & $0.70-1.24$ & 0.63 & 2.8 & $1.00-7.83$ \\
\hline
\end{tabular}

${ }^{a}$ Clear cell histology not informative. ${ }^{b} \mathrm{OR}=$ odds ratio; het = heterozygous OR; hom = homozygous OR. Studies included: ACS, AOCS, HAW, MALOVA, NCO, SWH, UKOPS; all ORs stratified on study site, age and race/ethnicity (for histology analyses).

data provided by OCAC sites, but no association was observed after replication genotyping was carried out in additional OCAC studies. The LIG4 variant, rs1805386, showed significant heterogeneity across studies $(P=0.001)$ for reasons that could not be elucidated. It is perplexing that the original data suggested a statistically significant positive association with risk, whereas the replication data suggested an inverse relationship. In the absence of any reasonable explanation it is likely that the heterogeneity was due to chance. The failure to replicate the association with the XRCC2 variant rs3218536 was not surprising as the evidence of association in the original data was weak under a co-dominant genetic model $(P=0.095)$.

Seven additional variants did not show an association with the risk of ovarian cancer in the OCAC dataset. Three of these variants have been studied by groups outside the OCAC: rs4680 (COMT) (Goodman et al, 2000), rs4646903 (CYP1A1, also known as CYP1A1 Msp1) (Sugawara et al, 2003) and rs1048943 (CYP1A1, also known as CYP1A1*3) (Aktas et al, 2002; Sugawara et al, 2003). Neither the COMT variant nor the CYP1A1 rs4646903 variant were associated with the risk of ovarian cancer on meta-analyses of the published literature and the OCAC data.

The CYP1A1 rs1048943 variant was associated with a nonstatistically significant increased risk of ovarian cancer per copy of the minor allele carried in the OCAC dataset and in a Japanese population $\left(\mathrm{OR}_{\mathrm{add}}=1.16,95 \% \mathrm{CI} 0.44-3.05\right)$ (Sugawara et al, $2003)$; in a Turkish population it was associated with a statistically significant increased risk of ovarian cancer $\left(\mathrm{OR}_{\mathrm{add}}=6.20,95 \% \mathrm{CI}\right.$ 3.62 -10.46) (Aktas et al, 2002). Overall, the meta-analysis of the published literature and the OCAC data showed a statistically significant increased risk of ovarian cancer $\left(\mathrm{OR}_{\mathrm{add}}=1.81,95 \% \mathrm{CI}\right.$ $1.36-2.40, P<0.001)$ under a fixed-effects model, but not a random-effects model $\left(\mathrm{OR}_{\mathrm{add}}=1.61,95 \% \mathrm{CI} 0.74-3.51, P=0.23\right)$. The meta-analysis also revealed significant heterogeneity across studies $(P<0.001)$ bringing this association into question. Further follow-up of this variant may be warranted.

There are several limitations to this study. The association with CYP3A4 rs2740574 was consistent in the original and replication

\section{REFERENCES}

Aktas D, Guney I, Alikasifoglu M, Yuce K, Tuncbilek E, Ayhan A (2002) CYP1A1 gene polymorphism and risk of epithelial ovarian neoplasm. Gynecol Oncol 86: $124-128$

Amirimani B, Ning B, Deitz AC, Weber BL, Kadlubar FF, Rebbeck TR (2003) Increased transcriptional activity of the CYP3A4* $1 \mathrm{~B}$ promoter variant. Environ Mol Mutagen 42: 299-305

Antoniou AC, Easton DF (2006) Risk prediction models for familial breast cancer. Future Oncol 2: 257-274

Auranen A, Song H, Waterfall C, Dicioccio RA, Kuschel B, Kjaer SK, Hogdall E, Hogdall C, Stratton J, Whittemore AS, Easton DF, Ponder BA, Novik KL, Dunning AM, Gayther S, Pharoah PD (2005) Polymorphisms in DNA repair genes and epithelial ovarian cancer risk. Int J Cancer 117: $611-618$

Ball SE, Scatina J, Kao J, Ferron GM, Fruncillo R, Mayer P, Weinryb I, Guida M, Hopkins PJ, Warner N, Hall J (1999) Population distribution data and was consistent across racial/ethnic groups, but it was restricted to homozygous carriers of the minor allele. The risk allele is rare in Whites and the result is based on few cases and while the SNP is common in Blacks there are few included in this study. Also, four of the SNPs (rs4646903 and rs1048943 in CYP1A1, rs1056836 in CYP1B1, and rs743572 in CYP17), which were not statistically significantly associated with ovarian cancer and therefore not followed up by the OCAC, were associated with $\sim 10 \%$ increased or decreased risk of ovarian cancer per copy of the allele carried. This size of effect is of the same magnitude as those observed in a recent breast cancer genome-wide association scan (Easton et al, 2007). Some of these results could be false negatives as we were only powered to detect odds ratios of $\sim 1.18$ and higher for these SNPs with $80 \%$ power and an $\alpha$ of 0.05 . We also observed significant heterogeneity with the SNP in LIG4, which may have been a chance finding, but may have resulted from underlying differences in the study populations, an issue with pooled-analyses.

In conclusion, we have identified a possible association between an SNP (rs2740574) in the key oestrogen-metabolizing gene CYP3A4 and ovarian cancer risk. Follow-up of this association is warranted, especially in Blacks. Our study also underscores the importance of consortium-based replication of genetic epidemiological studies to achieve large sample sizes.

\section{ACKNOWLEDGEMENTS}

We express our profound thanks to all the study participants who contributed to this research. Genotyping and the Ovarian Cancer Association Consortium are funded by the Ovarian Cancer Research Fund thanks to generous donations from the family and friends of Kathryn Sladek Smith.

Supplementary Information accompanies the paper on British Journal of Cancer website (http://www.nature.com/bjc) and effects on drug metabolism of a genetic variant in the $5^{\prime}$ promoter region of CYP3A4. Clin Pharmacol Ther 66: 288-294

Beesley J, Jordan SJ, Spurdle AB, Song H, Ramus SJ, Kjaer SK, Hogdall E, DiCioccio RA, McGuire V, Whittemore AS, Gayther SA, Pharoah PD, Webb PM, Chenevix-Trench G (2007) Association between singlenucleotide polymorphisms in hormone metabolism and DNA repair genes and epithelial ovarian cancer: results from two Australian studies and an additional validation set. Cancer Epidemiol Biomarkers Prev 16: $2557-2565$

Beral V, Bull D, Green J, Reeves G (2007) Ovarian cancer and hormone replacement therapy in the Million Women Study. Lancet 369: $1703-1710$

Berchuck A, Schildkraut JM, Wenham RM, Calingaert B, Ali S, Henriott A, Halabi S, Rodriguez GC, Gertig D, Purdie DM, Kelemen L, Spurdle AB, Marks J, Chenevix-Trench G (2004) Progesterone receptor promoter 
+331A polymorphism is associated with a reduced risk of endometrioid and clear cell ovarian cancers. Cancer Epidemiol Biomarkers Prev 13: $2141-2147$

Easton DF, Pooley KA, Dunning AM, Pharoah PD, Thompson D, Ballinger DG, Struewing JP, Morrison J, Field H, Luben R, Wareham N, Ahmed S, Healey CS, Bowman R, Luccarini C, Conroy D, Shah M, Munday H, Jordan C, Perkins B, West J, Redman K, Driver K, Meyer KB, Haiman CA, Kolonel LK, Henderson BE, Le Marchand L, Brennan P, Sangrajrang S, Gaborieau V, Odefrey F, Shen CY, Wu PE, Wang HC, Eccles D, Evans DG, Peto J, Fletcher O, Johnson N, Seal S, Stratton MR, Rahman N, Chenevix-Trench G, Bojesen SE, Nordestgaard BG, Axelsson CK, GarciaClosas M, Brinton L, Chanock S, Lissowska J, Peplonska B, Nevanlinna H, Fagerholm R, Eerola H, Kang D, Yoo KY, Noh DY, Ahn SH, Hunter DJ, Hankinson SE, Cox DG, Hall P, Wedren S, Liu J, Low YL, Bogdanova N, Schurmann P, Dork T, Tollenaar RA, Jacobi CE, Devilee P, Klijn JG, Sigurdson AJ, Doody MM, Alexander BH, Zhang J, Cox A, Brock IW, Macpherson G, Reed MW, Couch FJ, Goode EL, Olson JE, MeijersHeijboer H, van den Ouweland A, Uitterlinden A, Rivadeneira F, Milne RL, Ribas G, Gonzalez-Neira A, Benitez J, Hopper JL, McCredie M, Southey M, Giles GG, Schroen C, Justenhoven C, Brauch H, Hamann U, Ko YD, Spurdle AB, Beesley J, Chen X, Aghmesheh M, Amor D, Andrews L, Antill Y, Armes J, Armitage S, Arnold L, Balleine R, Begley G, Beilby J, Bennett I, Bennett B, Berry G, Blackburn A, Brennan M, Brown M, Buckley M, Burke J, Butow P, Byron K, Callen D, Campbell I, ChenevixTrench G, Clarke C, Colley A, Cotton D, Cui J, Culling B, Cummings M, Dawson SJ, Dixon J, Dobrovic A, Dudding T, Edkins T, Eisenbruch M, Farshid G, Fawcett S, Field M, Firgaira F, Fleming J, Forbes J, Friedlander M, Gaff C, Gardner M, Gattas M, George P, Giles G, Gill G, Goldblatt J, Greening S, Grist S, Haan E, Harris M, Hart S, Hayward N, Hopper J, Humphrey E, Jenkins M, Jones A, Kefford R, Kirk J, Kollias J, Kovalenko S, Lakhani S, Leary J, Lim J, Lindeman G, Lipton L, Lobb L, Maclurcan M, Mann G, Marsh D, McCredie M, McKay M, Anne McLachlan S, Meiser B, Milne R, Mitchell G, Newman B, O’Loughlin I, Osborne R, Peters L, Phillips K, Price M, Reeve J, Reeve T, Richards R, Rinehart G, Robinson B, Rudzki B, Salisbury E, Sambrook J, Saunders C, Scott C, Scott E, Scott R, Seshadri R, Shelling A, Southey M, Spurdle A, Suthers G, Taylor D, Tennant C, Thorne H, Townshend S, Tucker K, Tyler J, Venter D, Visvader J, Walpole I, Ward R, Waring P, Warner B, Warren G, Watson E, Williams R, Wilson J, Winship I, Young MA, Bowtell D, Green A, Defazio A, Chenevix-Trench G, Gertig D, Webb P, Mannermaa A, Kosma VM, Kataja V, Hartikainen J, Day NE, Cox DR, Ponder BA (2007) Genome-wide association study identifies novel breast cancer susceptibility loci. Nature 447: 1087 - 1093

Garner EI, Stokes EE, Berkowitz RS, Mok SC, Cramer DW (2002) Polymorphisms of the estrogen-metabolizing genes CYP17 and catechol$O$-methyltransferase and risk of epithelial ovarian cancer. Cancer Res 62: $3058-3062$

Gayther SA, Song H, Ramus SJ, Krüger Kjaer S, Whittemore A, Quaye L, Tyre J, Shadforth D, Hogdall E, Hogdall C, Blaeker J, DiCioccio R, McGuire V, Webb PM, Beesley J, Group TAOCS, Green AC, Whiteman DC, Cancer TACSO, Goodman MT, Lurie G, Carney ME, Modugno F, Ness RB, Edwards RP, Moysich KB, Goode EL, Couch FJ, Cunningham JM, Sellers TA, Wu AH, Pike MC, Iversen ES, Marks JR, Garcia-Closas M, Brinton L, Lissowska J, Peplonska B, Easton DF, Jacobs I, Ponder BAJ, Schildkraut J, Pearce CL, Chenevix-Trench G, Berchuck A, Pharoah PDP, Consortium obotOCA (2007) Tagging single nucleotide polymorphisms in cell cycle control genes and susceptibility to invasive epithelial ovarian cancer. Cancer Res 67: 3027-3035

Godard B, Foulkes WD, Provencher D, Brunet JS, Tonin PN, Mes-Masson AM, Narod SA, Ghadirian P (1998) Risk factors for familial and sporadic ovarian cancer among French Canadians: a case-control study. Am J Obstet Gynecol 179: $403-410$

Goodman JE, Lavigne JA, Hengstler JG, Tanner B, Helzlsouer KJ, Yager JD (2000) Catechol-O-methyltransferase polymorphism is not associated with ovarian cancer risk. Cancer Epidemiol Biomarkers Prev 9: 1373-1376

Goodman MT, McDuffie K, Guo C, Terada K, Donlon TA (2001a) CYP17 genotype and ovarian cancer: a null case-control study. Cancer Epidemiol Biomarkers Prev 10: $563-564$

Goodman MT, McDuffie K, Kolonel LN, Terada K, Donlon TA, Wilkens LR, Guo C, Le Marchand L (2001b) Case-control study of ovarian cancer and polymorphisms in genes involved in catecholestrogen formation and metabolism. Cancer Epidemiol Biomarkers Prev 10: 209-216

Holt SK, Rossing MA, Malone KE, Schwartz SM, Weiss NS, Chen C (2007) Ovarian cancer risk and polymorphisms involved in estrogen catabolism. Cancer Epidemiol Biomarkers Prev 16: 481 - 489
Ioannidis JP, Ntzani EE, Trikalinos TA, Contopoulos-Ioannidis DG (2001) Replication validity of genetic association studies. Nat Genet 29: 306-309

Keshava C, McCanlies EC, Weston A (2004) CYP3A4 polymorphismspotential risk factors for breast and prostate cancer: a HuGE review. Am J Epidemiol 160: $825-841$

Lander ES, Schork NJ (1994) Genetic dissection of complex traits. Science 265: $2037-2048$

Lichtenstein P, Holm NV, Verkasalo PK, Iliadou A, Kaprio J, Koskenvuo M, Pukkala E, Skytthe A, Hemminki K (2000) Environmental and heritable factors in the causation of cancer-analyses of cohorts of twins from Sweden, Denmark, and Finland. $N$ Engl J Med 343: 78-85

Lohmueller KE, Pearce CL, Pike M, Lander ES, Hirschhorn JN (2003) Metaanalysis of genetic association studies supports a contribution of common variants to susceptibility to common disease. Nat Genet 33: 177-182

Merritt MA, Green AC, Nagle CM, Webb PM (2008) Talcum powder, chronic pelvic inflammation and NSAIDs in relation to risk of epithelial ovarian cancer. Int J Cancer 122: $170-176$

Monroe KR, Murphy SP, Kolonel LN, Pike MC (2007) Prospective study of grapefruit intake and risk of breast cancer in postmenopausal women: the Multiethnic Cohort Study. Br I Cancer 97: 440-445

Pearce CL, Wu AH, Gayther SA, Bale AE, Beck PA, Beesley J, Chanock S, Cramer DW, Dicioccio R, Edwards R, Fredericksen ZS, Garcia-Closas M, Goode EL, Green AC, Hartmann LC, Hogdall E, Kjaer SK, Lissowska J, McGuire V, Modugno F, Moysich K, Ness RB, Ramus SJ, Risch HA, Sellers TA, Song H, Stram DO, Terry KL, Webb PM, Whiteman DC, Whittemore AS, Zheng W, Pharoah PD, Chenevix-Trench G, Pike MC, Schildkraut J, Berchuck A (2008a) Progesterone receptor variation and risk of ovarian cancer is limited to the invasive endometrioid subtype: results from the ovarian cancer association consortium pooled analysis. $\mathrm{Br} J$ Cancer 98: $282-288$

Pearce CL, Near AM, Butler JL, Van Den Berg D, Bretsky P, Conti DV, Stram DO, Pike MC, Hirschhorn JN, Wu AH (2008b) Comprehensive Evaluation of ESR2 Variation and Ovarian Cancer Risk. Cancer Epidemiol Biomarkers Prev 17: 393-396

Ramus SJ, Vierkant RA, Johnatty SE, Pike MC, Van Den Berg DJ, Wu AH, Pearce CL, Menon U, Gentry-Maharaj A, Gayther SA, Dicioccio RA, McGuire V, Whittemore AS, Song H, Easton DF, Pharoah PD, GarciaClosas M, Chanock S, Lissowska J, Brinton L, Terry KL, Cramer DW, Tworoger SS, Hankinson SE, Berchuck A, Moorman PG, Schildkraut JM, Cunningham JM, Liebow M, Kjaer SK, Hogdall E, Hogdall C, Blaakaer J, Ness RB, Moysich KB, Edwards RP, Carney ME, Lurie G, Goodman MT, Wang-Gohrke S, Kropp S, Chang-Claude J, Webb PM, Chen X, Beesley J, Chenevix-Trench G, Goode EL (2008) Consortium analysis of 7 candidate SNPs for ovarian cancer. Int J Cancer 123: 380-388

Risch N, Merikangas K (1996) The future of genetic studies of complex human diseases. Science 273: $1516-1517$

Rodriguez-Antona C, Sayi JG, Gustafsson LL, Bertilsson L, IngelmanSundberg M (2005) Phenotype-genotype variability in the human CYP3A locus as assessed by the probe drug quinine and analyses of variant CYP3A4 alleles. Biochem Biophys Res Commun 338: 299-305

Sellers TA, Schildkraut JM, Pankratz VS, Vierkant RA, Fredericksen ZS, Olson JE, Cunningham J, Taylor W, Liebow M, McPherson C, Hartmann LC, Pal T, Adjei AA (2005) Estrogen bioactivation, genetic polymorphisms, and ovarian cancer. Cancer Epidemiol Biomarkers Prev 14: 2536-2543

Song H, Ramus SJ, Quaye L, DiCioccio RA, Tyrer J, Lomas E, Shadforth D, Hogdall E, Hogdall C, McGuire V, Whittemore AS, Easton DF, Ponder BA, Kjaer SK, Pharoah PD, Gayther SA (2006) Common variants in mismatch repair genes and risk of invasive ovarian cancer. Carcinogenesis 27: 2235 - 2242

Spurdle AB, Chen X, Abbazadegan M, Martin N, Khoo SK, Hurst T, Ward B, Webb PM, Chenevix-Trench G (2000) CYP17 promotor polymorphism and ovarian cancer risk. Int I Cancer 86: 436-439

Spurdle AB, Goodwin B, Hodgson E, Hopper JL, Chen X, Purdie DM, McCredie MR, Giles GG, Chenevix-Trench G, Liddle C (2002) The CYP3A4*1B polymorphism has no functional significance and is not associated with risk of breast or ovarian cancer. Pharmacogenetics 12: 355-366

Stratton JF, Pharoah P, Smith SK, Easton D, Ponder BA (1998) A systematic review and meta-analysis of family history and risk of ovarian cancer. $\mathrm{Br}$ J Obstet Gynaecol 105: 493 -499

Sugawara T, Nomura E, Sagawa T, Sakuragi N, Fujimoto S (2003) CYP1A1 polymorphism and risk of gynecological malignancy in Japan. Int $J$ Gynecol Cancer 13: $785-790$

Terry KL, De Vivo I, Titus-Ernstoff L, Sluss PM, Cramer DW (2005) Genetic variation in the progesterone receptor gene and ovarian cancer risk. Am J Epidemiol 161: $442-451$ 
Terry KL, Titus-Ernstoff L, Garner EO, Vitonis AF, Cramer DW (2003) Interaction between CYP1A1 polymorphic variants and dietary exposures influencing ovarian cancer risk. Cancer Epidemiol Biomarkers Prev 12: $187-190$

Webb PM, Hopper JL, Newman B, Chen X, Kelemen L, Giles GG, Southey MC, Chenevix-Trench G, Spurdle AB (2005) Double-strand break repair gene polymorphisms and risk of breast or ovarian cancer. Cancer Epidemiol Biomarkers Prev 14: 319-323

Westlind A, Lofberg L, Tindberg N, Andersson TB, Ingelman-Sundberg $\mathrm{M}$ (1999) Interindividual differences in hepatic expression of CYP3A4: relationship to genetic polymorphism in the $5^{\prime}$-upstream regulatory region. Biochem Biophys Res Commun 259: $201-205$

\section{Appendix}

ACS/AOCS: The AOCS gratefully acknowledges the cooperation of the New South Wales, Queensland, South Australian, Victorian and Western Australian Cancer Registries as well as all the collaborating institutions represented within the AOCS Study Group which comprises: Management Group: D Bowtell (Peter MacCallum Cancer Centre, PMCC), G Chenevix-Trench, A Green, P Webb (Queensland Institute of Medical Research, QIMR), A deFazio (Westmead Hospital), D Gertig (University of Melbourne). Project Managers: N Traficante (PMCC), S Moore (QIMR), J Hung (Westmead Hospital). Data Managers: S Fereday (PMCC), K Harrap, T Sadkowsky (QIMR). Research Nurses: NSW - A Mellon, R Robertson (John Hunter Hospital), T Vanden Bergh (Royal Hospital for Women), J Maidens (Royal North Shore Hospital), K Nattress (Royal Prince Alfred Hospital), YE Chiew, A Stenlake, H Sullivan, (Westmead Hospital); QLD - B Alexander, P Ashover, S Brown, T Corrish, L Green, L Jackman, K Martin, B Ranieri (QIMR); SA- J White (QIMR); TAS- V Jayde (Royal Hobart Hospital); VIC - L Bowes (PMCC), P Mamers (Monash Medical Centre), WA - T Schmidt, H Shirley, S Viduka, H Tran, S Bilic, L Glavinas (Western Australia Research Tissue Network, WARTN). Clinical Collaborators: NSW - A Proietto, S Braye, G Otton (John Hunter Hospital); T Bonaventura, J Stewart (Newcastle Mater Misericordiae); M Friedlander (Prince of Wales Hospital); D Bell, S Baron-Hay, A Ferrier, G Gard, D Nevell, B Young (until mid 2003) (Royal North Shore Hospital); C Camaris, R Crouch, L Edwards, N Hacker, D Marsden, G Robertson (Royal Hospital for Women); P Beale, J Beith, J Carter, C Dalrymple, A Hamilton, R Houghton, P Russell (Royal Prince Alfred Hospital); A Brand, R Jaworski, P Harnett, G Wain (Westmead Hospital); QLD - A Crandon, M Cummings, K Horwood. A Obermair, D Wyld (Royal Brisbane and Women's Hospital, RBWH); J Nicklin (RBWH and Wesley Hospital), D Papadimos (SN Pathology), L Perrin (RBWH and Mater Misericordiae Hospitals), B Ward (Mater Misericordiae Hospitals); SA - M Davy, C Hall, T Dodd, T Healy, K Pittman (Royal Adelaide Hospital, Burnside Memorial Hospital); D Henderson, S Hyde (Flinders Medical Centre); J Miller, J Pierdes (Queen Elizabeth Hospital) TAS - P Blomfield, D Challis, R McIntosh, A Parker (Royal Hobart Hospital); VIC- B Brown, R Rome (Freemasons Hospital); D Allen, P Grant, S Hyde, R Laurie M Robbie, (Mercy Hospital for Women), D Healy, T Jobling, T Maniolitas, J McNealage, P Rogers, B Susil, A Veitch, J Constable, S Ping Tong, I Robinson, I Simpson, (Monash Medical Centre); K Phillips, D Rischin, P Waring, M Loughrey, N O'Callaghan, Bill
Murray (PMCC); V Billson, S Galloway, J Pyman, M Quinn (Royal Women's Hospital); WA - I Hammond, A McCartney, Y Leung (King Edward Memorial Hospital, St John of God). Scientific Collaborators: I Haviv (PMCC); D Purdie, D Whiteman (QIMR); N Zeps (WARTN). GCT, ABS and PW are supported by the NHMRC. Additional support was provided by: US Army Medical Research and Materiel Command under DAMD17-01-1-0729, the Cancer Council Tasmania and Cancer Foundation of Western Australia (AOCS study); The National Health and Medical Research Council of Australia (199600) (ACS study).

GEOCS: This work was funded by grants from the Roswell Park Alliance and National Institutes of Health Grants CA66190 and CA16056.

Hawaii: US Public Health Service grant R01-CA-58598, and contracts N01-CN-55424 and N01-PC-35137 from the National Cancer Institute, NIH, Department of Health and Human Services. HOPE: This work was funded by National Institutes of Health Grant R01CA095023 and DAMD 17-02-1-0669.

MAYO: This work was funded by National Institutes of Health Grants R01-CA86888 and R01-CA122443.

NECC: This work was funded by National Institutes of Health Grants 5P50CA105009 and 5RO1CA054419.

NCOCS: This work was funded by National Institutes of Health Grant 2-R01-CA76016.

SEARCH: This work was supported by Cancer Research-UK. We thank: Hannah Munday, Barbara Perkins, Mitul Shah, Clare Jordan, Judy West, Anabel Simpson, Sue Irvine, the search team: the local general practices and nurses and the East Anglian Cancer Registry for recruitment of the UK cases and the EPIC-Norfolk investigators for recruitment of the UK controls; PDPP is CRUK Senior Clinical Research Fellow.

UCI: This research was supported by the National Institutes of Health Grants CA-58860, CA-92044 and the Lon V Smith Foundation Grant LVS-39420.

UKOPS: We thank all members of the research team, including research nurses, research scientists, data entry personnel and consultant gynaecological oncologists for their help in establishing the UKOPS case-control collection. In particular, we thank Eva Wozniak for the efforts in genotyping and data analysis and Andy Ryan and Jeremy Ford for data and sample management.

USC: This work was funded by the California Cancer Research Program Grants 00-01389V-20170 and 2110200, US Public Health Service Grants CA14089, CA17054, CA61132, CA63464, N01-PC67010 and R03-CA113148, and California Department of Health Services subcontract 050-E8709 as part of its statewide cancer reporting programme. 